\title{
EFEK MEDIASI VARIABEL MOTIVASI PADA PENGARUH KOMITMEN ORGANISASI DAN DISIPLIN KERJA TERHADAP KINERJA PEGAWAI
}

\section{Nasruddin, Surajiyo, Suhaipa, Herman Paleni}

Universitas Bina Insan Sumatera Selatan, Indonesia

Email: nasruddin@univbinainsan.ac.id, surajiyo@univbinainsan.ac.id, suhaipa@univbinainsan.ac.id, herman_paleni@univbinainsan.ac.id

\begin{abstract}
Abstrak
Komitmen seorang pegawai merupakan hasil (resultante) dari dukungan dan penghargaan yang diberikan organisasi pada pegawai. Penelitian ini bertujuan untuk memperoleh hasil tentang pengaruh Komitmen Organisasi Terhadap Motivasi Pegawai, Disiplin Kerja Terhadap Motivasi Pegawai, Komitmen Organisasi Terhadap Kinerja Pegawai, Disiplin Kerja Terhadap Kinerja Pegawai, Motivasi Pegawai Terhadap Kinerja Pegawai, Motivasi dapat memediasi pengaruh komitmen organisasi terhadap kinerja pegawai, dan Motivasi dapat memediasi pengaruh disiplin kerja terhadap kinerja pegawai pada Lembaga Pemasyarakatan Narkotika Kelas II Lubuklinggau (Muara Beliti). Tahapan penelitian dengan melakukan observasi, pengelompokkan data hasil observasi, mengidentifikasi masalah, merumuskan masalah, penelusuran referensi/literatur, membuat kerangka berpikir dan hipotesis, menentukan teknik pengumpulan data, penentuan populasi dan sampel, membuat instrumen penelitian atau kuesioner, melakukan penyebaran kuesioner, menganalisis data dari hasil jawaban 96 pegawai ASN di Lembaga Pemasyarakatan Narkotika Klas IIA Lubuklinggau (Muara Beliti) menggunakan teknik analisis Structural Equation Modeling (SEM) dengan alat bantu komputer menggunakan program Lisrel 8.70. Adapun langkah-langkah Structural Equation Modeling (SEM) yang dilakukan Confirmatory Factor Analysis (CFA), Identifikasi model, modifikasi model dan menguji kecocokan model (Goodness-of-Fit). Hasil penelitian menunjukkan nilai koefesien pengaruh langsung komitmen organisasi terhadap motivasi pegawai sebesar 0,43 , dan nilai t hitung sebesar 3,35. Karena nilai t hitung sebesar $3.35>1,96$, maka komitmen organisasi berpengaruh signifikan terhadap motivasi pegawai. Dengan demikian dapat diinterpretasikan semakin tinggi komitmen organisasi, maka semakin tinggi motivasi pegawai.
\end{abstract}

Kata Kunci: komitmen organisasi; disiplin kerja; motivasi; kinerja

$\begin{array}{ll}\text { How to cite: } & \text { Nasruddin., N., et. al. (2021) Efek Mediasi Variabel Motivasi pada Pengaruh Komitmen Organisasi } \\ & \text { dan Disiplin Kerja Terhadap Kinerja Pegawai. Syntax Literate: Jurnal Ilmiah Indonesia, 6(10). } \\ & \text { http://dx.doi.org/10.36418/syntax-literate.v6i10.4377 } \\ & 2548-1398 \\ \text { E-ISSN: } & \text { Ridwan Institute }\end{array}$


Efek Mediasi Variabel Motivasi pada Pengaruh Komitmen Organisasi dan Disiplin Kerja Terhadap Kinerja Pegawai

\section{Abstract}

The commitment of an employee is the result (result) of the support and appreciation given by the organization to employees. In addition to employee commitment, employee work discipline such as obedience to organizational regulations also needs to be improved. Employee work discipline may be less adhered to without being supported by strong motivation. To improve employee performance, employee motivation becomes the spirit in spurring and growing morale at work. Someone has a spirit that comes from oneself or external factors that should be a person's motivation, not an inhibiting factor for employees. This study aims to obtain results about the effect of organizational commitment on employee motivation, work discipline on employee motivation, organizational commitment on employee performance, work discipline on employee performance, employee motivation on employee performance, motivation can mediate the effect of organizational commitment on employee performance, and motivation. can mediate the effect of work discipline on employee performance at the Class II Narcotics Correctional Institution Lubuklinggau (Muara Beliti). Stages of research by conducting observations, grouping observational data, identifying problems, formulating problems, searching references/literatures, making frameworks and hypotheses, determining data collection techniques, determining populations and samples, making research instruments or questionnaires, distributing questionnaires, analyzing data from the answers of 96 ASN employees at the Class IIA Narcotics Correctional Institution Lubuklinggau (Muara Beliti) using Structural Equation Modeling (SEM) analysis techniques with computer aids using the Lisrel 8.70 program. The steps of Structural Equation Modeling (SEM) carried out by Confirmatory Factor Analysis (CFA), identification of models, modification of models and testing of model fit (Goodness-of-Fit). The results showed that the coefficient value of the direct influence of organizational commitment on employee motivation was 0.43 , and the t-count value was 3.35. Because the $t$ value is $3.35>$ 1.96, organizational commitment has a significant effect on employee motivation.

Keywords: organizational commitment; work discipline; motivation; performance

Received: 2021-09-20; Accepted: 2021-10-05; Published: 2021-10-20

\section{Pendahuluan}

Sumber Daya Manusia dalam suatu organisasi memegang peran sentral demi pencapaian tujuan organisasi, hal ini terlihat dari kinerja yang dihasilkan oleh pegawai. Kinerja pegawai yang meningkat akan turut mempengaruhi/meningkatkan prestasi organsasi tempat pegawai yang bersangkutan bekerja, sehingga tujuan organisasi yang telah ditentukan dapat dicapai. Kinerja mempunyai makna yang lebih luas, bukan hanya hasil kerja, tetapi termasuk bagaimana proses pekerjaan berlangsung (Afandi, 2018). Sedangkan Levinson mendefinisikan kinerja atau unjuk kerja adalah pencapaian atau prestasi seseorang berkenaan dengan tugas-tugas yang dibebankan kepadanya (Marwansyah et al., 2016).

Kinerja yang baik bukanlah suatu kebetulan saja, tetapi banyak faktor yang mempengaruhi di antaranya komitmen pegawai, disiplin kerja dan motivasi. Pentingnya 
komitmen pegawai terhadap organisasi, karena dengan komitmen yang tinggi dari pegawai, maka kinerja yang dihasilkan akan baik. Kreitner dan Kinicki menyatakan komitmen adalah kesepakatan untuk melakukan sesuatu untuk diri sendiri, individu lain, kelompok atau organisasi sedangkan Ivancevich, konopaske, dan matteson menyatakan bahwa komitmen adalah perasaan identifikasi, pelibatan dan loyalitas dinyatakan oleh pekerja terhadap perusahaan. Lebih lanjut Schermerhorn, Hunt Osborn dan Uhl-Bien menyatakan komitmen sebagai loyalitas seorang individu pada organisasi (Nikmah et al., 2019).

Komitmen yang tinggi dari pegawai berhubungan erat dengan kinerja pegawai. Komitmen merupakan variabel intrinsik, semestinya dimiliki oleh setiap pegawai. Komitmen seorang pegawai dimanifestasikan dalam bentuk rasa memiliki yang tinggi terhadap organisasi. Rasa memiliki (sense of belonging) yang tinggi terhadap organisasi merupakan hasil (resultante) dari dukungan dan penghargaan yang diberikan organisasi pada pegawai. Kurangnya dukungan dan pengharagaan berdampak turunnya rasa memiliki terhadap organisasi, yang pada akhirnya berdampak pada turunnya komitmen pegawai.

Selain komitmen pegawai, disiplin kerja pegawai seperti ketaataan atas peraturan organisasi juga perlu ditingkatkan. Disiplin adalah sikap kesediaan dan kerelaan seseorang untuk mematuhi dan menaati norma-norma dan peraturan yang berlaku disekitarnya, selain itu disiplin adalah prilaku seseorang yang sesuai dengan peraturan, prosedur kerja yang ada.

Disiplin kerja pegawai barangkali menjadi kurang ditaati tanpa didukung dengan motivasi yang kuat. Motivasi adalah keinginan yang timbul dari dalam diri seseorang atau individu karena terinspirasi, tersemangati dan terdorong untuk melakukan aktifitas dengan keihklasan, senang hati dan sungguh-sungguh sehingga hasil dari aktifitas yang dia lakukan mendapat hasil yang baik dan berkualitas (Afandi, 2018). Untuk meningkatkan kinerja pegawai, motivasi dari diri pegawai menjadi spirit dalam memacu dan menumbuhkan semangat kerja dalam bekerja. Seseorang memiliki spirit bersumber dari diri sendiri atau faktor luar yang seharusnya menjadi motivasi seseorang bukan menjadi faktor penghambat bagi pegawai.

Lembaga Pemasyarakatan Narkotika Klas IIA Lubuklinggau (Muara Beliti) merupakan salah satu Unit Pelaksana Teknis (UPT) Pemasyarakatan yang berada dalam wilayah kerja Kantor Wilayah Kementerian Hukum dan Hak Asasi Manusia Provinsi Sumatera Selatan. Tugas pokok melaksanakan pemasyarakatan narapidana/ Warga Binaan Pemasyarakatan (WBP) tindak pidana narkotika, psikotropika, dan bahan adiktif lainnya (narkoba). Tugas pembinaan bagi Narapidana secara berkala dan berkelanjutan dengan tujuan agar narapidana menyadari kesalahannya dan tidak lagi berkehendak melakukan tindak pidana dan menjadi warga masyarakat yang bertanggung jawab bagi dirinya sendiri, keluarga dan lingkungannya. Berdasarkan tugas pokok untuk melaksanakan pembinaan inilah, maka komitmen pegawai, disiplin kerja dan motivasi sangat penting bagi tercapainya kinerja pegawai sesuai tujuan organisasi. 
Berbagai penelitian tentang komitmen organisasi dan disiplin kerja terhadap motivasi maupun terhadap kinerja sudah banyak dilakukan oleh peneliti sebelumnya, Persamaannya diantaranya: Prabowo, Italina Anidar, Suyanto, Veronica, Sujiati, Selviasari dan Fatmah, dimana hasil penelitian menyatakan komitmen organisasi dan disiplin kerja berpengaruh dan signifikan terhadap motivasi maupun terhadap kinerja. Namun perbedaan hasil penelitiannya, penelitian yang dilakukan Prabowo, menggunakan analisis data dengan menggunakan regresi 2 (dua) jalur dan metode sobel untuk menguji mediasinya,dengan pengolahan data menggunakan program SPSS. Hasil analisis variabel mediasi dengan menggunakan uji Sobel, menemukan motivasi kerja dapat memediasi pengaruh komitmen organisasi terhadap kinerja pegawai. Motivasi kerja dapat memediasi pengaruh disiplin kerja terhadap kinerja pegawai. Penelitian yang dilakukan Italina, variabel independen yang diteliti kepemimpinan, motivasi kerja, dan kedisiplinan. Dalam penelitian ini ditemukan variabel komitmen organisasi dapat memediasi secara mediasi parsial (partial mediation) hubungan antara kepemimpinan, motivasi kerja, dan kedisiplinan terhadap kinerja pegawai. Penelitian yang dilakukan Anidar, bahwa kemampuan kerja berpengaruh signifikan terhadap motivasi kerja dan kinerja pegawai. Pengaruh tidak langsung kemampuan kerjaterhadap kinerja melalui motivasi memiliki pengaruh yang lebih besar dari pada pengaruh tidak langsung komitmen terhadap kinerja melalui motivasi. Hasil penelitian (Suyanto, 2018) menunjukkan bahwa kompetensi dan disiplin berpengaruh secara simultan terhadap motivasi kerja anggota dewan. Secara parsial, motivasi kerja lebih dipengaruhi oleh kompetensi daripada disiplin. Hasil penelitian juga menunjukkan bahwa kompetensi, disiplin dan motivasi kerja berpengaruh secara simultan terhadap kinerja.

Hasil penelitian lainnya yang dilakukan Veronica, menunjukkan bahwa komitmen organisasional, disiplin kerja dan kompensasi non finansial secara simultan dan parsial berpengaruh positif dan signifikan terhadap kinerja karyawan. Hasil penelitian Sujiati menggunakan Structural Equation Modeling (SEM) PLS. Hasilnya menunjukkan bahwa motivasi berpengaruh signifikan baik langsung maupun tidak langsung melalui kompetensi terhadap kinerja karyawan. Hasil penelitian Selviasari menyebutkan gaya kepemimpinan Situasional dan Kompensasi berpengaruh terhadap kinerja melalui motivasi sebagai variabel intervening. Variabel motivasi menjadi variabel intervening karena perhitungan koefisien standar untuk pengaruh tidak langsung gaya kepemimpinan Situasional dan Kompensasi Kinerja melalui motivasi kerja adalah lebih besar daripada pengaruh langsung Gaya Kepemimpinan Situasional dan Kompensasi terhadap kinerja. Sedangkan berdasarkan hasil penelitian Fatmah, bahwa kepemimpinan dan disiplin kerja berpengaruh negatif terhadap komitmen organisasi. Hasil penelitian juga menunjukkan bahwa kepemimpinan, disiplin kerja, dan komitmen organisasi berpengaruh positif terhadap kinerja karyawan. Penelitian ini juga memberikan hasil bahwa komitmen organisasi tidak dapat memediasi kepemimpinan dan disiplin kerja terhadap kinerja pegawai.

Adapun tujuan penelitian ini untuk memperoleh hasil tentang pengaruh komitmen organisasi terhadap motivasi pegawai, disiplin kerja terhadap motivasi pegawai, 
komitmen organisasi terhadap kinerja pegawai, disiplin kerja terhadap kinerja pegawai, motivasi pegawai terhadap kinerja pegawai, motivasi dapat memediasi pengaruh komitmen organisasi terhadap kinerja pegawai, dan Motivasi dapat memediasi pengaruh disiplin kerja terhadap kinerja pegawai pada Lembaga Pemasyarakatan Narkotika Kelas II Lubuklinggau (Muara Beliti).

\section{Metode Penelitian}

Pendekatan dalam penelitian ini menggunakan pendekatan kuantitatif dengan menggunakan metode survey pada pegawai di Lembaga Pemasyarakatan Narkotika Kelas II Lubuklinggau (Muara Beliti).

Teknik pengumpulan data yang dilakukan adalah observasi, dokumentasi, dan penyebaran kuesioner kepada 96 pegawai di Lembaga Pemasyarakatan Narkotika Kelas IIA Lubuklinggau (Muara Beliti). Populasi dalam penelitian ini adalah 96 Pegawai di Lembaga Pemasyarakatan Narkotika Klas IIA Lubuklinggau (Muara Beliti). Sampel dalam penelitian ini menggunakan seluruh anggota populasi yang berjumlah 96 orang pegawai di Lembaga Pemasyarakatan Narkotika Klas IIA Lubuklinggau (Muara Beliti).

\section{Teknik Analisis Data}

Teknik analisis yang dapat digunakan pada metode Structural Equetion Modeling (SEM) (Haryono, 2016):

\section{a. Spesifikasi Model}

Spesifikasi model dalam penelitian ini dilakukan untuk mengetahui model memenuhi spesifikasi atau tidak.

\section{b. Identifikasi Model}

Jika parameter memiliki nilai yang sama di semua set ekuivalen, maka parameternya diidentifikasi.

\section{c. Analisis Faktor Konfirmatori}

Variabel amatan dikatakan signifikan apabila nilai-t diperoleh minimal sebesar 1.96 untuk taraf $\alpha 5 \%$, dan 2.58 untuk taraf $\alpha 10 \%$. Suatu indikator dikatakan valid jika hasil pengujian menunjukkan signifikan dan memiliki loadingfactor minimal sebesar 0.05. sedangkan Tingkat reliabilitas yang diterima adalah apabila nilai Construct Reliability $(\mathrm{CR}) \geq 0,7$ meskipun harga tersebut bukanlah sebuah harga "mati" (Gunarto, 2018).

\section{d. Modifikasi Model}

Modifikasi model dapat dilakukan jika model yang dihasilkan tidak fit atau tidak cocok. Suatu model dikatakan fit jika matriks residunya (Fitted Residuals) adalah nol (mendekati nol). Sedangkan model dikatakan memiliki fit yang sangat buruk apabila matriks residunya sangat besar

\section{e. Menguji Kecocokan Model}

Setelah estimasi parameter model SEM diperoleh, maka model fit, marginal fit atau tidak fit (Riadi, 2018). 
Efek Mediasi Variabel Motivasi pada Pengaruh Komitmen Organisasi dan Disiplin Kerja Terhadap Kinerja Pegawai

\section{Hasil dan Pembahasan}

\section{A. Pengujian Model ( Measurement Model )}

Dalam pengujian model dilakukan menggunakan Confirmatory Factor Analysis (CFA) secara First Order Confirmatory Factor Analysis (CFA):

\section{First Order Confirmatory konstruk variabel Komitmen Organisasi}

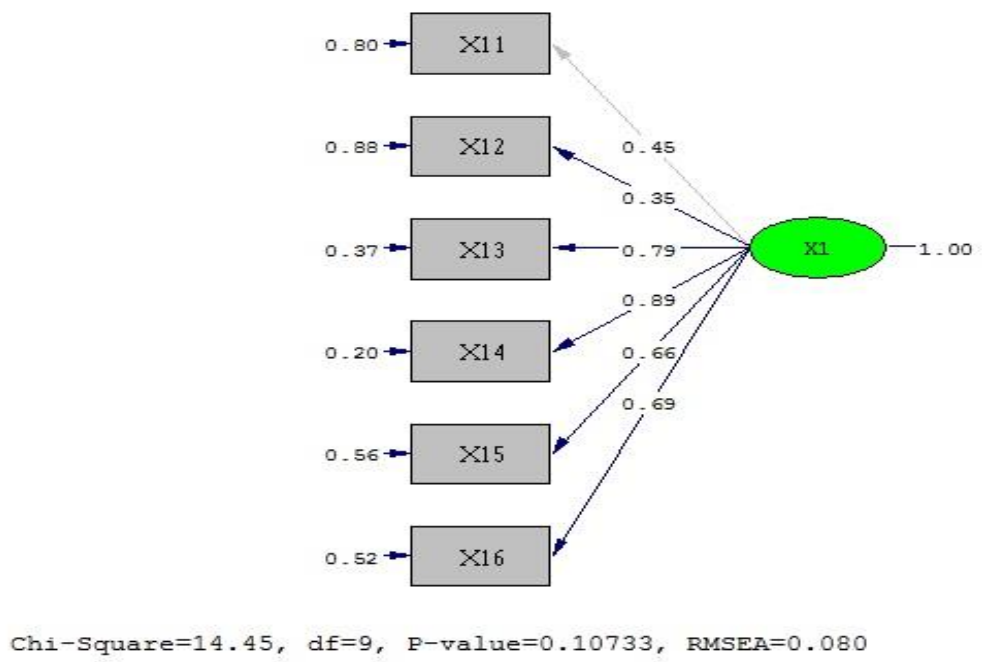

Gambar 1

Hasil Pengujian First Order Confirmatory Komitmen Organisasi

Dari hasil estimasi loading factorvariabel manifest komitmen organisasi terdapat variabel manifest X11 dan X12nilainya kurang dari 0,5, dengan demikian butir pernyataantersebut dibuang dan tidak digunakan untuk pengujian hipotesis, sehingga hasil perbaikan konstruk variabel komitmen organisasi dapat dilihat pada gambar 3 .

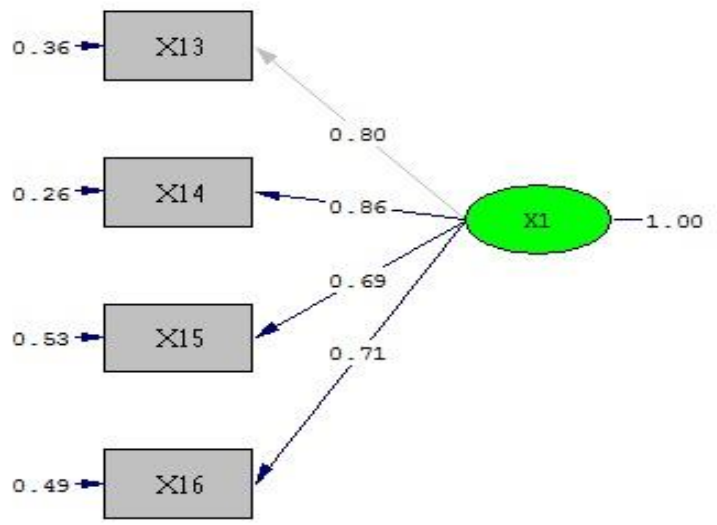

Chi-Square=4.02, $d f=2, P$-value=0.13374, RMSEA=0.103

Gambar 2

Hasil Pengujian First Order Confirmatory Komitmen Organisasi setelah di Modifikasi 
Dari gambar 3, terlihat bahwa, untuk variabel manifest X11 dan X12 sudah dibuang dan variabel konstruk komitmen organiisasi sudah dapat digunakan untuk pengujian hipotesis.

2. First Order Confirmatory konstruk variabel Disiplin Kerja

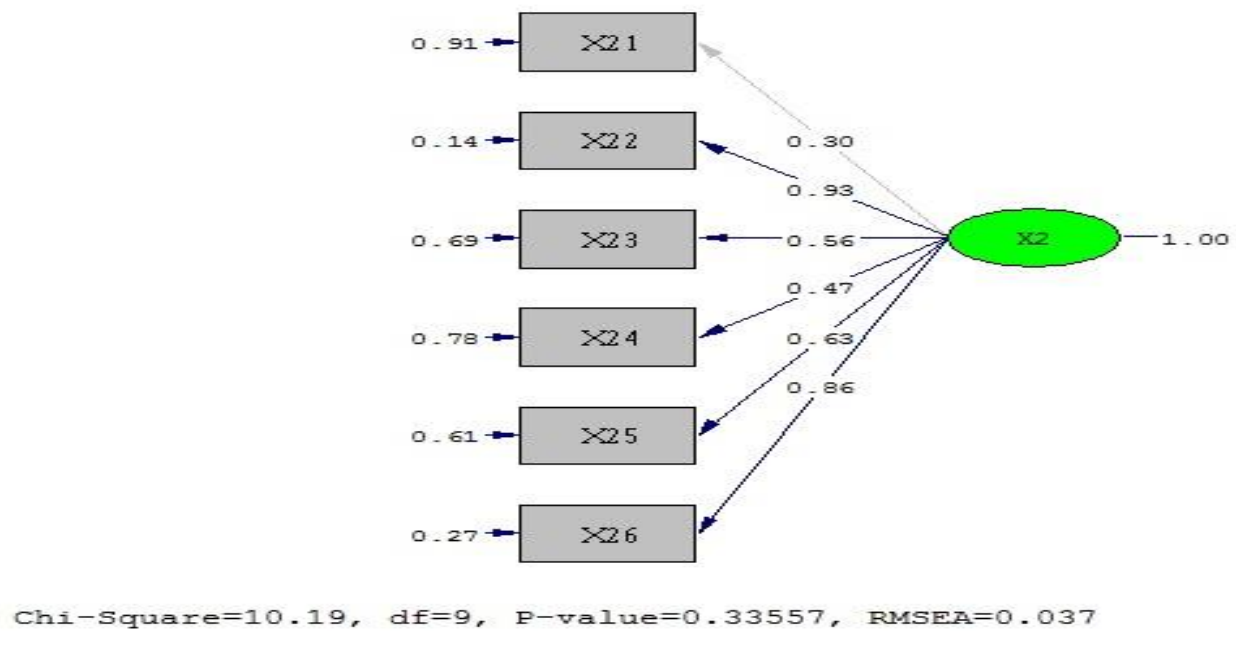

Gambar 3

Hasil Pengujian First Order ConfirmatoryDisiplin Kerja

Dari hasil estimasi loading factorvariabel manifest disiplin kerja terdapat variabel manifest X21 dan X24 nilainya kurang dari 0,5, dengan demikian butir pernyataantersebut dibuang dan tidak digunakan untuk pengujian hipotesis, sehingga hasil perbaikan konstruk variabel disiplin kerja dapat dilihat seperti gambar 5.

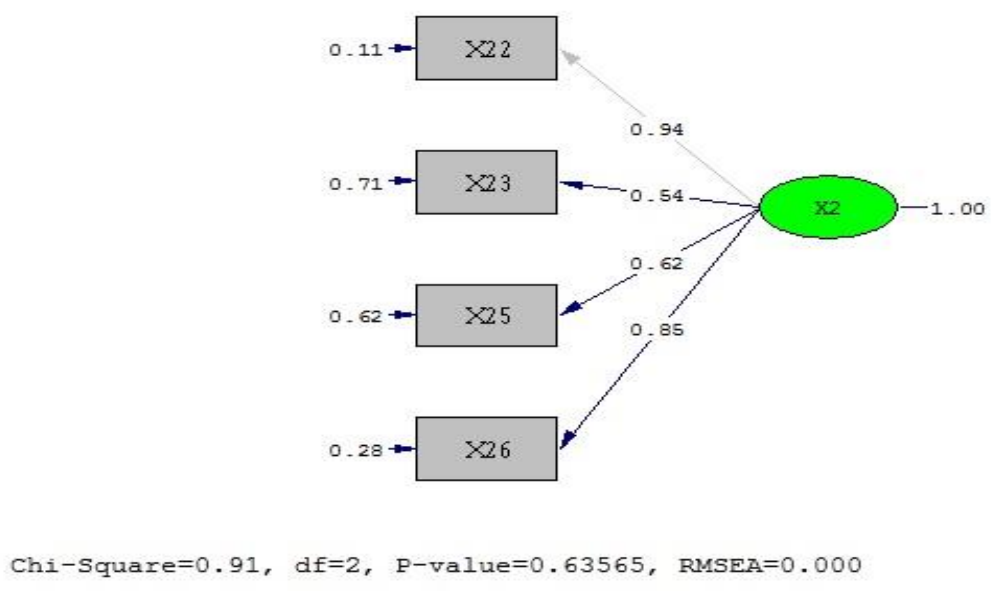

Gambar 4

Hasil Pengujian First Order ConfirmatoryVariabel Disiplin Kerja setelah di modifikasi 
Efek Mediasi Variabel Motivasi pada Pengaruh Komitmen Organisasi dan Disiplin Kerja Terhadap Kinerja Pegawai

Berdasarkan gambar 5, terlihat bahwa untuk variabel manifest X21 dan $X 24$ sudah dibuang dan variabel konstruk disiplin kerja sudah dapat digunakan untuk pengujian hipotesis.

\section{First Order Confirmatory Variabel Motivasi}
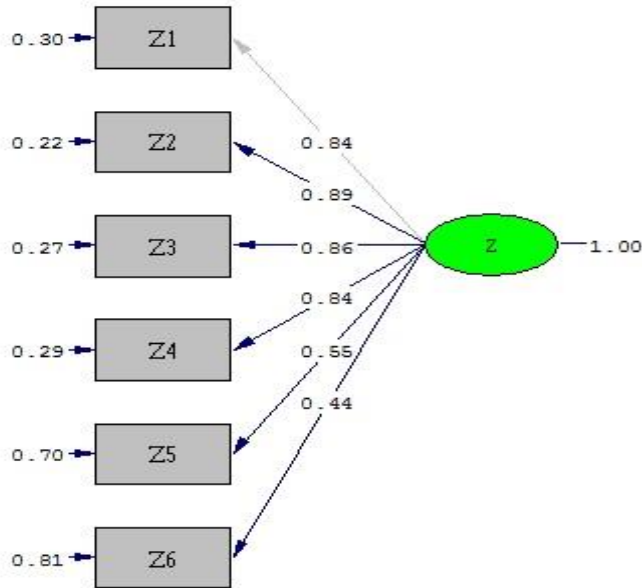

Chi-Square $=44.88, d f=9, P-v a l u e=0.00000$, RMSEA $=0.205$

\section{Gambar 5 \\ Hasil pengujian First Order Confirmatory) Variabel Motivasi}

Berdasarkan gambar 6, hasil estimasi loading factorvariabel manifest motivasi terdapat variabel manifest Z6 nilainya kurang dari 0,5, dengan demikian butir pernyataantersebut dibuang dan tidak digunakan untuk pengujian hipotesis, sehingga hasil perbaikan konstruk variabel motivasi dapat dilihat pada gambar 6.

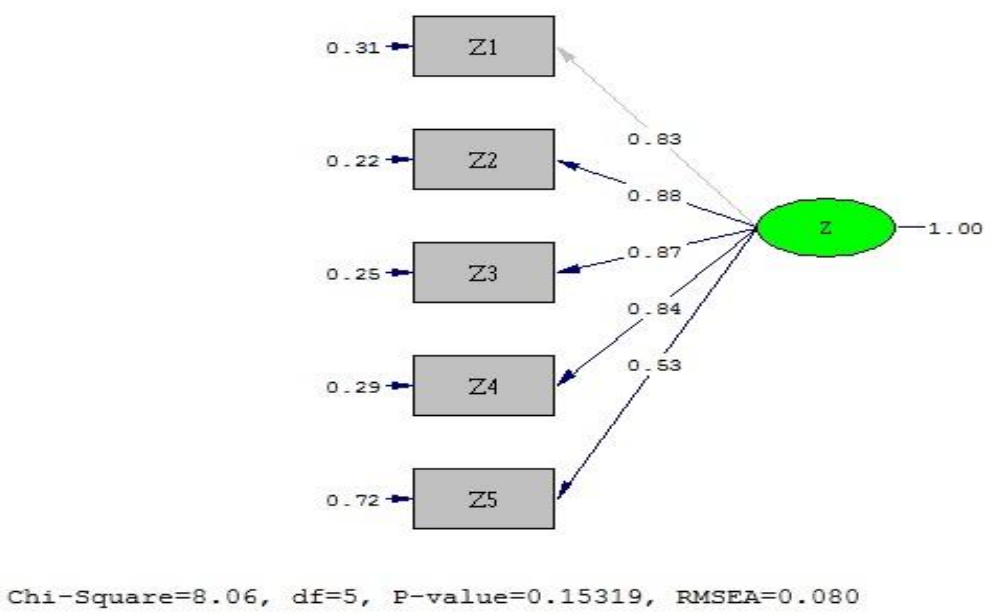

Gambar 6

Hasil Pengujian First Order Confirmatory Variabel Motivasi setelah di Modifikasi 
Berdasarkan gambar 7, terlihat bahwa untuk variabel manifest Z6sudah dibuang dan variabel konstruk motivasi sudah dapat digunakan untuk pengujian hipotesis.

\section{First Order Confirmatory Variabel Kinerja}

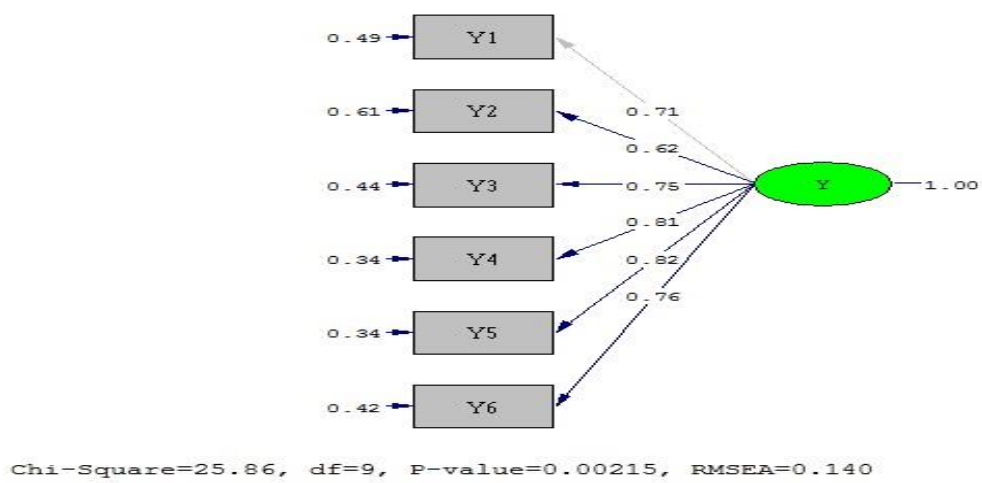

Gambar 7

Hasil pengujian First Order Confirmatory Variabel Kinerja

Berdasarkan gambar 8, terlihat bahwa seluruh variabel manifest dari variabel konstruk nilainya lebih dari 0,5 , dengan demikian seluruh butir pernyataandapat digunakan untuk pengujian hipotesis.

\section{Pengujian Full Model Structural}

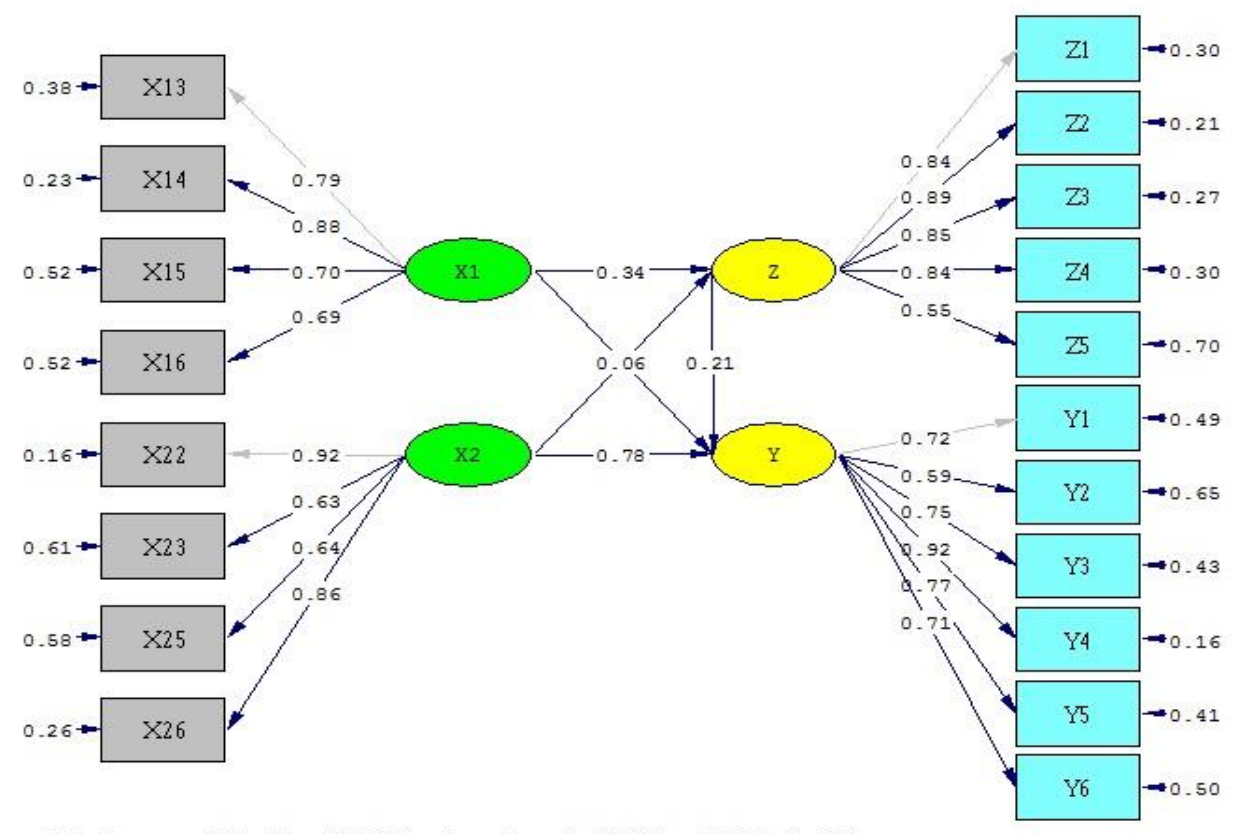

Chi-Square $=455.88, d f=147, P-v a l u e=0.00000$, RMSEA $=0.149$

\section{Gambar 8}

Hasil pengujian Full Model Structural 
Efek Mediasi Variabel Motivasi pada Pengaruh Komitmen Organisasi dan Disiplin Kerja Terhadap Kinerja Pegawai

Berdasarkan gambar 9 full model structural, maka nilai loading faktor variabel manifest seluruhnya lebih besar dari 0,5, maka sudah dapat dilakukan untuk pengujian hipotesis.

B. Uji Validitas dan Reliabilitas Full Model Structural

a. Uji Validitas

Tabel 1

Hasil Validitas Variabel Konstruk Full Model Structural

\begin{tabular}{|c|c|c|c|c|}
\hline Variabel Laten & $\begin{array}{l}\text { Variabel } \\
\text { Manifest }\end{array}$ & $\begin{array}{c}\text { Estimasi } \\
\text { Loading } \\
\text { Factor }\end{array}$ & $\begin{array}{c}\text { Critical } \\
\text { Value }\end{array}$ & Keputusan \\
\hline \multirow{4}{*}{$\begin{array}{l}\text { Komitmen } \\
\text { Organisasi }\end{array}$} & $\mathrm{X} 13$ & 0,80 & 0,5 & Valid \\
\hline & $\mathrm{X} 14$ & 0,86 & 0,5 & Valid \\
\hline & X15 & 0,69 & 0,5 & Valid \\
\hline & $\mathrm{X} 16$ & 0,71 & 0,5 & Valid \\
\hline \multirow{4}{*}{ Disiplin Kerja } & $\mathrm{X} 22$ & 0,94 & 0,5 & Valid \\
\hline & $\mathrm{X} 23$ & 0,54 & 0,5 & Valid \\
\hline & $\mathrm{X} 25$ & 0,62 & 0,5 & Valid \\
\hline & $\mathrm{X} 26$ & 0,85 & 0,5 & Valid \\
\hline \multirow{5}{*}{ Motivasi } & $\mathrm{Z1}$ & 0,83 & 0,5 & Valid \\
\hline & $\mathrm{Z} 2$ & 0,88 & 0,5 & Valid \\
\hline & $\mathrm{Z3}$ & 0,87 & 0,5 & Valid \\
\hline & $\mathrm{Z4}$ & 0,84 & 0,5 & Valid \\
\hline & $\mathrm{Z} 5$ & 0.53 & & \\
\hline \multirow{6}{*}{ Kinerja } & Y1 & 0,71 & 0,5 & Valid \\
\hline & Y2 & 0,62 & 0,5 & Valid \\
\hline & Y3 & 0,75 & 0,5 & Valid \\
\hline & Y4 & 0,81 & 0,5 & Valid \\
\hline & Y5 & 0,82 & 0,5 & Valid \\
\hline & Y6 & 0,76 & 0,5 & Valid \\
\hline
\end{tabular}

Data diolah menggunakan Lisrel 8.70, tahun 2021

Dari hasil estimasi loading factor seluruh variabel komitmen organisasi, disiplin kerja, motivasi dan kinerja lebih besar dari 0,5, dengan demikian seluruh butir pernyataan pada kuisioner variabel konstruksudah dikatakan valid dan sudah dapat di gunakan untuk pengujian hipotesis.

b. Uji Reliabilitas

Tabel 2

Hasil Reliabiltas Variabel Konstruk Full Model Structural

\begin{tabular}{rccccc}
\hline Variabel Laten & Manifest & $\begin{array}{c}\text { Loading } \\
\text { Factor }\end{array}$ & $\begin{array}{c}\text { Critical } \\
\text { Value }\end{array}$ & CR & Keputusan \\
\hline & X13 & 0,80 & 0,5 & & Reliabel \\
Komitmen & X14 & 0,86 & 0,5 & 0,85 & Reliabel \\
Organisasi & X15 & 0,69 & 0,5 & & Reliabel \\
& X16 & 0,71 & 0,5 & & Reliabel \\
\hline
\end{tabular}




\begin{tabular}{cccccc}
\hline Variabel Laten & Manifest & $\begin{array}{c}\text { Loading } \\
\text { Factor }\end{array}$ & $\begin{array}{c}\text { Critical } \\
\text { Value }\end{array}$ & CR & Keputusan \\
\hline \multirow{3}{*}{ Komitmen } & X13 & 0,80 & 0,5 & & Reliabel \\
Organisasi & X14 & 0,86 & 0,5 & 0,85 & Reliabel \\
& X15 & 0,69 & 0,5 & & Reliabel \\
& X16 & 0,71 & 0,5 & & Reliabel \\
\hline \multirow{5}{*}{ Disiplin Kerja } & X22 & 0,94 & 0,5 & & Reliabel \\
& X23 & 0,54 & 0,5 & \multirow{2}{*}{0,84} & Reliabel \\
& X25 & 0,62 & 0,5 & & Reliabel \\
& X26 & 0,85 & 0,5 & & Reliabel \\
\hline \multirow{5}{*}{ Motivasi } & Z1 & 0,83 & 0,5 & & Reliabel \\
& Z2 & 0,88 & 0,5 & & Reliabel \\
& Z3 & 0,87 & 0,5 & 0,90 & Reliabel \\
& Z4 & 0,84 & 0,5 & & Reliabel \\
& Z5 & 0.53 & 0,5 & & Reliabel \\
\hline \multirow{5}{*}{ Kinerja } & Y1 & 0,71 & 0,5 & & Reliabel \\
& Y2 & 0,62 & 0,5 & & Reliabel \\
& Y3 & 0,75 & 0,5 & \multirow{2}{*}{0,88} & Reliabel \\
& Y4 & 0,81 & 0,5 & & Reliabel \\
& Y5 & 0,82 & 0,5 & & Reliabel \\
& Y6 & 0,76 & 0,5 & & Reliabel \\
\hline
\end{tabular}

Data diolah menggunakan Lisrel 8.70, tahun 2021

Dari hasil estimasi loading factor seluruh variabel komitmen organisasi, disiplin kerja, motivasi dan kinerja lebih besar dari 0,5, dengan demikian seluruh butir pernyataan pada kuisioner variabel konstruksudah dikatakan reliabel dan sudah dapat di gunakan untuk pengujian hipotesis.

c. Uji kecocokan Model ( Goodness of Fit Index)

Tabel 3

Goodness of Fit Index Variabel Konstruk Full Model Structural

\begin{tabular}{cccc}
\hline Indikator & Cut-off Value & Hasil & Kesimpulan \\
\hline $\begin{array}{c}\text { Chi-square }(\mathrm{df}=130, \\
\mathrm{p}=0,00)\end{array}$ & $<420.41$ & 415.21 & Fit \\
\hline GFI & $\geq 0.90$ & 0.67 & Tidak Fit \\
\hline AGFI & $\geq 0.90$ & 0.57 & Tidak Fit \\
\hline CFI & $\geq 0.90$ & 0.91 & Fit \\
\hline TLI/NNFI & $\geq 0.90$ & 0.90 & Fit \\
\hline NFI & $\geq 0.90$ & 0.88 & Marginal Fit \\
\hline IFI & $\geq 0.90$ & 0.91 & Fit \\
\hline PGFI & $>0,5$ & 0.51 & Fit \\
\hline RFI & $\geq 0.90$ & 0.86 & Marjinal Fit \\
\hline RMSEA & $\leq 0.08$ & 0.15 & Tidak Fit \\
\hline RMR & $\leq 0,05$ & 0.05 & Fit \\
\hline
\end{tabular}

Data diolah menggunakan Lisrel 8.70, tahun 2021

Berdasarkan hasil analisis di atas, diperoleh hasil estimasi GOF secara umum berkategori Fit, maka secara keseluruhan dapat disimpulkan model fit 
artinya matrik kovarian sampel relatif samadengan matrik kovarian estimasi, sehingga sudah dapat di gunakan untuk pengujian hipotesis.

\section{Hasil Pengujian hipotesis}

Berdasarkan hasil pengolahan data, diperoleh persamaan struktural:

$\mathrm{Z}=0.43 * \mathrm{X} 1+0.54 * \mathrm{X} 2$, Errorvar. $=0.18, \mathrm{R}^{2}=0.59$

(0.13) (0.10)

$3.35 \quad 5.40$

$\mathrm{Y}=0.13 * \mathrm{X} 1+0.68 * \mathrm{X} 2$, Errorvar. $=0.015, \mathrm{R}^{2}=0.94$

(0.062) (0.086)

$2.07 \quad 7.95$

$\mathrm{Y}=0.16 * \mathrm{Z}+0.060 * \mathrm{X} 1+0.60 * \mathrm{X} 2$, Errorvar. $=0.0100, \mathrm{R}^{2}=0.96$

(0.066) (0.063) (0.086)

$2.48 \quad 0.95 \quad 6.94$

Dari persamaan struktural di atas, untuk pengujian hipotesis masing-masing seperti di bawah ini:

1. Komitmen Organisasi Terhadap Motivasi Pegawai pada Lembaga Pemasyarakatan Narkotika Kelas II Lubuklinggau (Muara Beliti)

Nilai Koefesien pengaruh komitmen organisasiterhadap motivasipegawaisebesar 0,43 , dan nilai t hitung sebesar 3,35. Karena nilai t hitung sebesar 3.35> 1,96, maka komitmen organisasiberpengaruh signifikan terhadap motivasi pegawai. Dengan demikian hipotesis pertama komitmen organisasiberpengaruh signifikanterhadap motivasi pegawai pada Lembaga Pemasyarakatan Narkotika Kelas II Lubuklinggau (Muara Beliti) dapat diterima. Dengan demikian dapat diinterpretasikan semakin tinggi komitmen organisasi, maka semakin tinggi motivasi pegawai. Hasil penelitian ini sama dengan hasil penelitianPrabowo, bahwa komitmen organisasi berpengaruh signifikanterhadap kinerja (Prabowo, 2020), demikian pula halnya dengan hasil penelitian lainnya (Bagis et al., 2020); (Italina et al., 2020), dan (Adil et al., 2018) bahwa komitmen organisasi berpengaruh signifikanterhadap motivasi Pegawai.

2. Disiplin Kerja Terhadap Motivasi Pegawai pada Lembaga Pemasyarakatan Narkotika Kelas II Lubuklinggau (Muara Beliti)

Nilai koefesien pengaruh disiplin kerja terhadap motivasi pegawai sebesar 0,54 dan nilai t hitung sebesar 5,40. Karena nilai t hitung sebesar 5,40> 1,96, maka dapat diketahui bahwa disiplin kerja berpengaruh signifikan terhadap motivasi pegawai. Dengan demikian hipotesis kedua Disiplin Kerja berpengaruh signifikan Terhadap Motivasi Pegawaipada Lembaga Pemasyarakatan Narkotika Kelas II Lubuklinggau (Muara Beliti) dapat diterima, sehingga dapat diinterpretasikan semakin tinggi disiplin kerja, maka semakin tinggi motivasi 
pegawai. Hasil penelitian ini sama dengan hasil penelitian Prabowo, bahwa disiplin kerja berpengaruh signifikanterhadap motivasi (Prabowo, 2020).

3. Komitmen Organisasi Terhadap Kinerja Pegawai pada Lembaga Pemasyarakatan Narkotika Kelas II Lubuklinggau (Muara Beliti)

Nilai koefesien pengaruh komitmen organisasi terhadap kinerja pegawai sebesar 0,13,. Dan nilai t hitung sebesar 2,07. Karena nilai t hitung sebesar 2.07> 1,96 , hal ini menunjukkan bahwa komitmen organisasi berpengaruh signifikan terhadap kinerja pegawai. Dengan demikian hipotesis ketiga komitmen organisasiberpengaruh signifikan Terhadap kinerja pegawai pada Lembaga Pemasyarakatan Narkotika Kelas II Lubuklinggau (Muara Beliti) dapat diterima, sehingga dapat dikatakan bahwa komitmen organisasi berpengaruh signifikan terhadap Kinerja Pegawai pada Lembaga Pemasyarakatan Narkotika Kelas II Lubuklinggau (Muara Beliti). Dengan demikian dapat diinterpretasikan semakin tinggi komitmen organisasi, maka semakin tinggi kinerja pegawai. Hasil penelitian ini sama dengan hasil penelitian Prabowo, bahwa komitmen organisasiberpengaruh signifikanterhadap kinerja (Prabowo, 2020), demikian pula halnya dengan hasil penelitian lainnya (Bagis et al., 2020); (Italina et al., 2020), dan (Adil et al., 2018) bahwa komitmen organisasi berpengaruh signifikanterhadap Kinerja Pegawai.

4. Disiplin Kerja berpengaruh signifikan Terhadap Kinerja Pegawai pada Lembaga Pemasyarakatan Narkotika Kelas II Lubuklinggau (Muara Beliti)

Nilai oefesien pengaruh disiplin kerja terhadap kinerja pegawai sebesar 0,68, dan nilai t hitung sebesar 7,95. Karena nilai t hitung sebesar 7,95> 1,96, maka diketahui bahwa disiplin kerja berpengaruh signifikan terhadap kinerja pegawai. Dengan demikian hipotesis keempat disiplin kerja berpengaruh signifikan terhadap kinerja pegawaipada Lembaga Pemasyarakatan Narkotika Kelas II Lubuklinggau (Muara Beliti) dapat diterima, sehingga dapat diinterpretasikan semakin tinggi disiplin kerja, maka semakin tinggi kinerja pegawai. Hasil penelitian ini sama dengan hasil penelitian Prabowo, bahwa disiplin kerja berpengaruh signifikanterhadap kinerja (Prabowo, 2020), demikian juga halnya dengan hasil penelitian (Suyanto, 2018).

5. Motivasi Pegawai berpengaruh signifikan Terhadap Kinerja Pegawai pada Lembaga Pemasyarakatan Narkotika Kelas II Lubuklinggau (Muara Beliti)

Nilai koefesien pengaruh motivasi pegawai terhadap kinerja pegawai sebesar 0,16, dan nilai t hitung 2,48, karena nilai t hitung sebesar 2,48>1,96, hal ini menunjukkan bahwa motivasi pegawai berpengaruh signifikan terhadap kinerja pegawai. Dengan demikian hipotesis kelimamotivasi pegawai berpengaruh signifikan terhadap kinerja pegawai pada Lembaga Pemasyarakatan Narkotika Kelas II Lubuklinggau (Muara Beliti) dapat diterima.Hasil penelitian ini sama dengan hasil penelitian Prabowo, bahwa motivasi berpengaruh signifikan terhadap kinerja (Prabowo, 2020), demikian pula halnya dengan hasil penelitian (Anidar \& Indarti, 2015); (Selviasari, 2019); (Sujiati et al., 2017); 
(Bagis et al., 2020); (Italina et al., 2020), dan (Adil et al., 2018). Dengan demikian dapat diinterpretasikan semakin tinggi motivasi, maka semakin tinggi kinerja pegawai.

6. Motivasi memediasi pengaruh komitmen organisasi terhadap kinerja pegawai pada Lembaga Pemasyarakatan Narkotika Kelas II Lubuklinggau (Muara Beliti)

Untuk mengetahui efek mediasi pada variabel laten, maka dilakukan pengujian padapengaruh langsung, tidak langsung dan pengaruh total. Analisis pengaruh ditujukan untuk melihat seberapa kuat pengaruh suatu variabel dengan variabel lainnya baik secara langsung dan tidak langsung. Berdasarkan hasil pengolahan data tentang pengaruh langsung dan tidak langsung, serta pengaruh total seperti pada tabel.4, tabel. 5, dan tabel. 6:

\section{Tabel 4}

Pengaruh Langsung

\begin{tabular}{lccc}
\hline Variabel Laten & $\begin{array}{c}\text { Komitmen } \\
\text { Organisasi }\end{array}$ & $\begin{array}{c}\text { Disiplin } \\
\text { Kerja }\end{array}$ & Motivasi \\
\hline Motivasi & 0.43 & 0.54 & - \\
\hline Kinerja & 0.13 & 0.68 & 0.16 \\
\hline
\end{tabular}

Data diolah menggunakan Lisrel 8.70, tahun 2021

Tabel 5

Pengaruh Tidak Langsung

\begin{tabular}{lccc}
\hline Variabel Laten & $\begin{array}{c}\text { Komitmen } \\
\text { Organisasi }\end{array}$ & $\begin{array}{c}\text { Disiplin } \\
\text { Kerja }\end{array}$ & Motivasi \\
\hline Motivasi & - & - & - \\
\hline Kinerja & 0.07 & 0.12 & 0.21 \\
\hline
\end{tabular}

Data diolah menggunakan Lisrel 8.70, tahun 2021

Tabel 6

Pengaruh Total

\begin{tabular}{lccc}
\hline Variabel Laten & $\begin{array}{c}\text { Komitmen } \\
\text { Organisasi }\end{array}$ & $\begin{array}{c}\text { Disiplin } \\
\text { Kerja }\end{array}$ & Motivasi \\
\hline Motivasi & 0.43 & 0.54 & - \\
\hline Kinerja & 0.20 & 0.80 & 0.37 \\
\hline
\end{tabular}

Data diolah menggunakan Lisrel 8.70, tahun 2021

Berdasarkan hasil perhitungan pada tabel 4, mengenai pengaruh langsung antara komitmen organisasi terhadap kinerja pegawai melalui motivasi, menunjukkan bahwa motivasi memiliki pengaruh langsung lebih besar terhadap kinerja $(0,43)$ daripada pengaruh langsung komitmen organisasi terhadap kinerja $(0,13)$.

Berdasarkan tabel 5, menunjukkan hasil perhitungan pengaruh tidak langsung daripada komitmen organisasi dan disiplin kerja terhadap kinerja 
melalui motivasi, menunjukkan bahwa motivasi memiliki pengaruh tidak langsung lebih besar $(0,21)$ daripada komitmen organisasi $(0.07)$ dan disiplin kerja $(0,12)$.

Berdasarkan tabel 6 menunjukkan hasil perhitungan pengaruh total dari komitmen organisasi dan disiplin kerja terhadap kinerja melalui motivasi dan menunjukkan bahwa disiplin kerja memiliki pengaruh total lebih besar terhadap motivasi $(0,50)$ daripada pengaruh total komitmen organisasi $(0,43)$ terhadap motivasi. Pengaruh total disiplin kerja lebih besar terhadap kinerja $(0,80)$ daripada pengaruh total komitmen organisasi $(0,20)$ terhadap kinerja, sedangkan pengaruh total motivasi terhadap kinerja sebesar 0,37 .

Besarnya pengaruh langsung, pengaruh tidak langsung dan pengaruh total masing-masing hubungan variabel terlihat seperti pada tabel :

\section{Tabel 7}

Pengaruh Langsung dan Tidak Langsung Hubungan

KomitmenOrganisasiterhadap Kinerja pegawai melalui Motivasi

\begin{tabular}{cccccccc} 
No & Hubungan & $\begin{array}{c}\text { Pengaruh } \\
\text { Langsung }\end{array}$ & $\begin{array}{c}\text { Pengaruh } \\
\text { tidak } \\
\text { langsung }\end{array}$ & $\begin{array}{c}\text { Pengaruh } \\
\text { Total }\end{array}$ & $\mathrm{t}_{\text {value }}$ & $\mathrm{t}_{\text {tabel }}$ & Ket \\
\hline 1 & $\begin{array}{l}\text { Komitmen } \\
\text { Organisasi - } \\
\text { Motivasi }\end{array}$ & 0.43 & - & 0.43 & 3.35 & 1,96 & Signifikan \\
\hline $\begin{array}{l}\text { Komitmen } \\
\text { Organisasi - } \\
\text { Kinerja }\end{array}$ & 0.13 & 0.07 & 0.20 & 2.07 & 1,96 & Signifikan \\
\hline 3 & $\begin{array}{l}\text { Motivasi - } \\
\text { Kinerja }\end{array}$ & 0.16 & 0.21 & 0.37 & 2.48 & 1,96 & Signifikan \\
\hline
\end{tabular}

Data diolah menggunakan Lisrel 8.70, tahun 2021

Berdasarkan tabel 7, terlihat besaran pengaruh langsung dan tidak langsung masing-masing hubungan, sehingga motivasimenjadi variabel mediasi yang sempurna bagi hubungan antara komitmen organisasi dengan kinerja. Dengan demikian hipotesis yang menyatakan motivasimemediasi pengaruh komitmen organisasi terhadap kinerja padaLembaga Pemasyarakatan Narkotika Kelas II Lubuklinggau (Muara Beliti) dapat diterima. Hal ini menunjukkan bahwa ada pengaruh tidak langsung motivasi dalam hubungan komitmen organisasi terhadapkinerjapegawai dengan total pengaruh tidak langsung sebesar 0,28 dan signifikan.Hasil penelitian ini sama dengan hasil penelitian Prabowo dan Anidar, bahwa motivasidapat memediasi pengaruh komitmen organisasi secara signifikan terhadap kinerja (Prabowo, 2020) dan juga sama dengan hasil penelitian (Anidar \& Indarti, 2015) bahwa motivasimampu memediasi pengaruh komitmen organisasi secara signifikan terhadap kinerja.

7. Motivasi memediasi pengaruh disiplin kerja terhadap kinerja pegawai pada Lembaga Pemasyarakatan Narkotika Kelas II Lubuklinggau (Muara 
Efek Mediasi Variabel Motivasi pada Pengaruh Komitmen Organisasi dan Disiplin Kerja Terhadap Kinerja Pegawai

\section{Beliti)}

Besarnya pengaruh langsung, pengaruh tidak langsung dan pengaruh total masing-masing hubungan variabel terlihat seperti tabel di bawah ini:

\section{Tabel 8}

Pengaruh Langsung dan Tidak Langsung Hubungan Disiplin Kerjaterhadap Kinerja pegawai melalui motivasi

\begin{tabular}{cccccccc}
\hline No & Hubungan & $\begin{array}{c}\text { Pengaruh } \\
\text { Langsung }\end{array}$ & $\begin{array}{c}\text { Pengaruh } \\
\text { tidak } \\
\text { langsung }\end{array}$ & $\begin{array}{c}\text { Pengaruh } \\
\text { Total }\end{array}$ & $\mathrm{t}_{\text {value }}$ & $\mathrm{t}_{\text {tabel }}$ & Ket \\
\hline 1 & $\begin{array}{l}\text { Disiplin } \\
\text { Kerja - } \\
\text { Motivasi }\end{array}$ & 0.54 & - & 0.57 & 5.40 & 1.96 & Signifikan \\
\hline $\begin{array}{l}\text { Disiplin } \\
\text { Kerja - } \\
\text { Kinerja }\end{array}$ & 0.68 & 0.12 & 0.82 & 7.95 & 1,96 & Signifikan \\
\hline 3 & $\begin{array}{l}\text { Motivasi- } \\
\text { Kinerja }\end{array}$ & 0.16 & 0.21 & 0.37 & 2.48 & 1,96 & Signifikan \\
\hline
\end{tabular}

Data diolah menggunakan Lisrel 8.70, tahun 2021

Berdasarkan tabel 8, terlihat besaran pengaruh langsung dan tidak langsung masing-masing hubungan, sehingga motivasi menjadi variabel mediasi yang sempurna bagi hubungan antara disiplin kerja dengan kinerja pegawai dengan total pengaruh tidak langsung sebesar 0,33. Dengan demikian hipotesis yang menyatakan motivasi memediasi pengaruh disiplin kerja terhadap kinerja pegawai pada Lembaga Pemasyarakatan Narkotika Kelas II Lubuklinggau (Muara Beliti) dapat diterima. Hasil penelitian ini sama dengan hasil penelitian Prabowo, bahwa motivasimampumemediasi pengaruh disiplin kerja secara signifikan terhadap kinerja.

\section{Kesimpulan}

Berdasarkan hasil dan pembahasan, maka dapat disimpulkan nilai koefesien pengaruh langsung komitmen organisasi terhadap motivasi pegawai sebesar 0,43, dan nilai t hitung sebesar 3,35. Karena nilai t hitung sebesar 3,35>1,96, maka komitmen organisasi berpengaruh signifikan terhadap motivasi pegawai. Dengan demikian dapat diinterpretasikan semakin tinggi komitmen organisasi, maka semakin tinggi motivasi pegawai. Nilai koefesien pengaruh langsung disiplin kerja terhadap motivasi pegawai sebesar 0,54 dan nilai t hitung sebesar 5,40. Karena nilai t hitung sebesar 5,40>1,96, maka disiplin kerja berpengaruh signifikan terhadap motivasi pegawai. Dengan demikian dapat diinterpretasikan semakin tinggi disiplin kerja, maka semakin tinggi motivasi pegawai. Nilai koefesien pengaruh langsung komitmen organisasi terhadap kinerja pegawai sebesar 0,13 ,. Dan nilai t hitung sebesar 2.07. Karena nilai t hitung sebesar 2.07> 1,96, hal ini menunjukkan bahwa komitmen organisasi berpengaruh signifikan terhadap kinerja pegawai. Dengan demikian dapat diinterpretasikan semakin 
tinggi komitmen organisasi, maka semakin tinggi kinerja pegawai. Nilai koefesien pengaruh langsung disiplin kerja terhadap kinerja pegawai sebesar 0,68, dan nilai $\mathrm{t}$ hitung sebesar 7,95. Karena nilai t hitung sebesar 7,95> 1,96, maka dapat diketahui bahwa disiplin kerja berpengaruh signifikan terhadap kinerja pegawai. Dengan demikian dapat diinterpretasikan semakin tinggi disiplin kerja, maka semakin tinggi kinerja pegawai. Nilai koefesien pengaruh langsung motivasi pegawai terhadap kinerja pegawai sebesar 0,16, dan nilai t hitung 2,48, karena nilai t hitung sebesar 2,48>1,96, hal ini menunjukkan bahwa motivasi pegawai berpengaruh signifikan terhadap kinerja pegawai. Dengan demikian dapat diinterpretasikan semakin tinggi motivasi, maka semakin tinggi kinerja pegawai. Nilai pengaruh tidak langsung komitmen organisasi terhadap kinerja melalui motivasi sebesar 0,28. Hal ini menunjukkan motivasi mampu menjadi variabel mediasi sebesar $28 \%$ bagi hubungan antara komitmen organisasi dengan kinerja. Nilai pengaruh tidak langsung disiplin kerja terhadap kinerja melalui motivasi sebesar 0,33 . Hal ini menunjukkan motivasi mampu menjadi variabel mediasi sebesar $33 \%$ bagi hubungan antara disiplin kerja dengan kinerja pegawai. 
Efek Mediasi Variabel Motivasi pada Pengaruh Komitmen Organisasi dan Disiplin Kerja Terhadap Kinerja Pegawai

\section{BIBLIOGRAFI}

Adil, V. M., Sendow, G. M., \& Lumintang, G. G. (2018). Pengaruh Komitmen Organisasional, Disiplin Kerja Dan Kompensasi Non Finansial Terhadap Kinerja Karyawan Pada Dinas Ketenagakerjaan Dan Transmigrasi Prov. Sulawesi Utara. Jurnal Emba: Jurnal Riset Ekonomi, Manajemen, Bisnis Dan Akuntansi, 6(4). Google Scholar

Afandi, P. (2018). Manajemen Sumber Daya Manusia (Teori, Konsep Dan Indikator). Riau: Zanafa Publishing. Google Scholar

Anidar, K. H., \& Indarti, S. (2015). Pengaruh Kemampuan Dan Komitmen Terhadap Motivasi Dan Kinerja Pegawai Pada Sekretariat Daerah Kabupaten Natuna. Jurnal Tepak Manajemen Bisnis, 7(3), 357-376. Google Scholar

Bagis, F., Darmawan, A., \& Hidayah, A. (2020). The Effect Of Leadership, Work Disiplin On Employee Performance Trough Organizational Commitment As Mediation Variables. International Journal Of Economics, Business And Accounting Research (Ijebar), 4(03). Google Scholar

Gunarto, M. (2018). Analisis Statistika Dengan Model Persamaan Struktural (Sem): Teoritis Dan Praktis. Bandung: Alfabeta. Google Scholar

Haryono, S. (2016). Metode Sem Untuk Penelitian Manajeman Dengan Amos Lisrel Pls (Vol. 53, Issue 9). Google Scholar

Italina, C., Apridar, A., \& Ratna, R. (2020). Pengaruh Kepemipinan, Motivasi Dan Kedisplinan Terhadap Komitmen Organisasi Dan Dampaknya Terhadap Kinerja Pegawai Pada Dinas Pertanian Kabupaten Pidie. J-Mind (Jurnal Manajemen Indonesia), 4(1), 15-29. Google Scholar

Marwansyah, M. S. D. M., Dua, E., \& Keempat, C. (2016). Bandung: Cv. Alfabeta. Google Scholar

Nikmah, N., Julkawait, J., \& Irwansyah, R. (2019). Manajemen Kinerja Jurusan Akuntansi Politeknik Negeri Banjarmasin. Proceeding Of National Conference On Asbis, 4, 230-238. Google Scholar

Riadi, E. (2018). Statistik Sem Structural Equation Modeling Dengan Lisrel. Yogyakarta: Cv Andi Offset. Google Scholar

Selviasari, R. (2019). Effect Of Situational Leadership Style, Compensation And Motivation On Employee Performance In Pt. Bank Rakyat Indonesia (Persero), Tbk. Kediri Branch. Journal Of Engineering And Management In Industrial System, 7(1), 40-52. Google Scholar

Sujiati, S., Ma'arif, M. S., \& Najib, M. (2017). The Effect Of Motivation And Competence On Employee Performance In Satellite Technology Center-National 
Nasruddin, Surajiyo, Suhaipa, Herman Paleni

Institute Aeronautics And Space. Jurnal Aplikasi Manajemen, 15(2), 229-237. Google Scholar

Sutrisno. (2012). Manajemen Keuangan Teori Konsep Dan Aplikasi. Ekonisia. Google Scholar

Sutrisno, E. (2013). Manajemen Sumber Daya Manusia. Google Scholar

Suyanto, S. (2018). Competence And Discipline On Work Motivation And The Implication On Working Performance. Google Scholar

\section{Copyright holder:}

Nasruddin, Surajiyo, Suhaipa, Herman Paleni (2021)

First publication right:

Syntax Literate: Jurnal Ilmiah Indonesia

This article is licensed under:

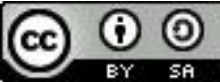

